\title{
Unicentric retroperitoneal Castleman disease: Report of 3 cases
}

\section{Unisentrik retroperitoneal Castleman hastalığı: 3 olgunun sunumu}

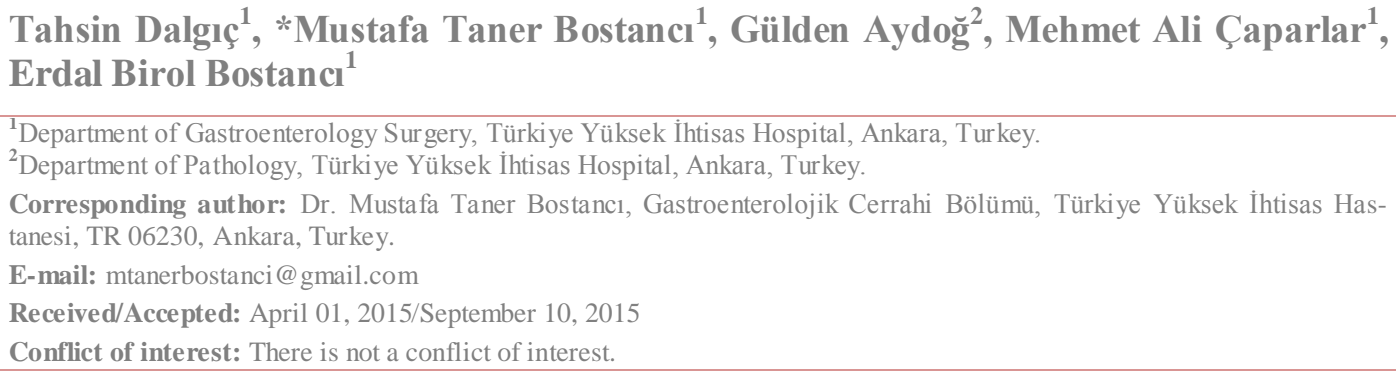

\section{SUMMARY}

Castleman Disease is a rare lymphoproliferative disorder mainly occuring in the mediastinum. Abdominal forms are less frequent and manifests rarely as an isolated retroperitoneal mass. The diagnosis is based on postoperative pathological findings. Herein, we report three cases of unicentric retroperitoneal Castleman Disease from our center. Three women were detected to have a retroperitoneal mass in the medical examinations. The masses were surgically removed and histopathological examination revealed a hyaline- vascular type of Castleman disease. Although retroperitoneal Castleman Disease is rare, it should be considered in the differential diagnosis of retroperitoneal masses.

Keywords: Castleman Disease, retroperitoneal mass

ÖZET

Castleman Hastalığı daha çok mediastinumda görülen nadir bir lenfoproliferatif hastalıktır. Abdominal formları nadir görülürler ve çok nadir olarak izole retroperitoneal bir kitle şeklinde ortaya çıkarlar. Tanı postoperatif patolojik bulgulara göre koyulur. Bildirimizde karşılaştığımız üç unisentrik retroperitoneal Castleman Hastalığı olan hastayı sunduk. Medikal muayeneler sonucu üç kadın hastada retroperitoneal kitle tespit edildi. Kitleler cerrahi olarak çıkarıldı ve histopatolojik inceleme sonucu hiyalin-vasküler tip Castleman Hastalığı tespit edildi. Castleman Hastalığı nadir olmasına rağmen retroperitoneal kitlelerin ayırıcı tanısında düşünülmelidir.

Anahtar sözcüikler: Castleman Hastalığı, retroperitoneal kitle

\section{INTRODUCTION}

Unicentric Castleman Disease (CD) which is also known as giant lymph node hyperplasia, follicular lymphoreticuloma or angiofollicular mediastinal lymph node hyperplasia is an uncommon lymphoproliferative disorder with unknown aetiology. It is first described by Benjamin Castleman in 1956 in tumors of the thymus with clinically asymptomatic mediastinal lymph node hyperplasia ${ }^{1}$. Flendrig and Schillings ${ }^{2}$ described two distinct pathologic types and one mixed variant, while Keller et al. ${ }^{3}$ reported hyaline-vascular, plasma cell and hyaline-vascular plasma cell type. Little is known about the cause of this disease, which may occur anywhere along the lymphatic chain, but it is most commonly located in the mediastinum ${ }^{4}$. It usually presents as a localized soft tissue mass in the neck or the mediastinum; however, it has also been reported that the mesentery, pelvis, pancreas, adrenal and retroperitoneum may also be included in other extrathoracic involvement ${ }^{4-7}$. The localized form is considered as benign and multicentric type as aggressive ${ }^{8}$. The therapeutic options are not standardized due to differential clinical 
presentation of the disease. In this report, we present three cases of unicentric Castleman Disease of the hyaline-vascular type with retroperitoneal location.

\section{CASE REPORT}

In our report, all of the patients were women and they were 19, 52, 56 years old, respectively. None of them had a remarkable medical history. The first and the third patient presented with epigastric pain; but the second patient was asymptomatic and the mass was detected by ultrasonographic examination in a routine examination. On physical examination, only the first patient who was 19 year old had a palpabl mass in the epigastrium; the others did not have any remarkable findings. All patients were examined systematically by abdominal ultrasonography, computed tomography (CT), magnetic resonance imaging (MRI) and endoscopic ultrasound (EUS) and we detected radiographically resectable masses (Figure1).
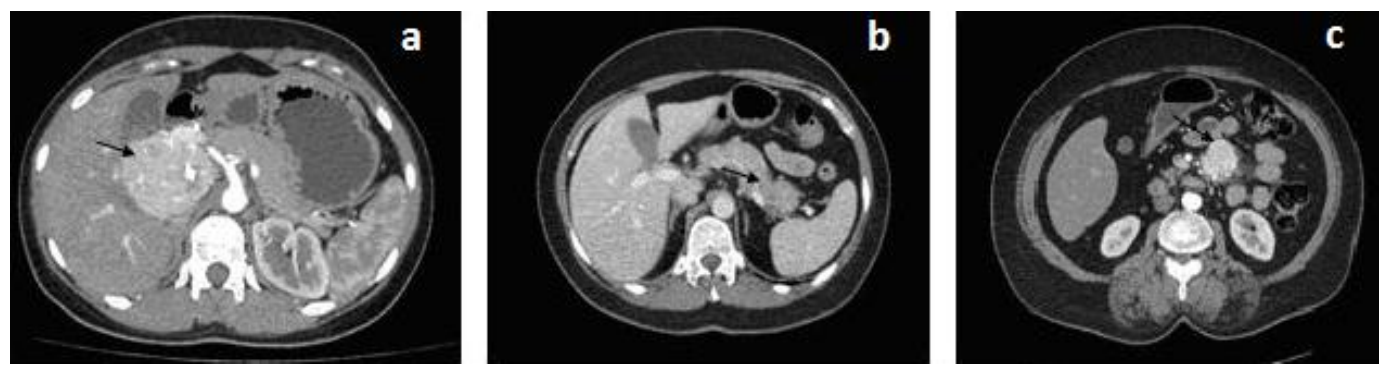

Figure1: CT images of the masses. A heterogenous mass at the posterior part of portal con-

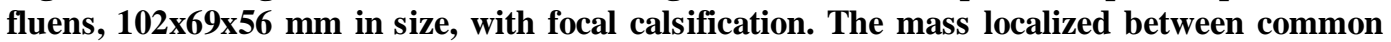
$V$. porta and $V$. cava inferior, and compressed these vessels. The lesion pushed duodenum and the head of the pancreas to the anterior but there was no evidence of invasion of surrounding structures or vessels; b) a mass $35 \times 30 \mathrm{~mm}$ in diameter was noted at posterior part of the pancreatic tail. The mass was well-demarcated and localized between A. splenica and V. Renalis sinistra; c) A mass $45 \times 40 \mathrm{~mm}$ in diameter was noted at inferior part of the duodenum segment 4.
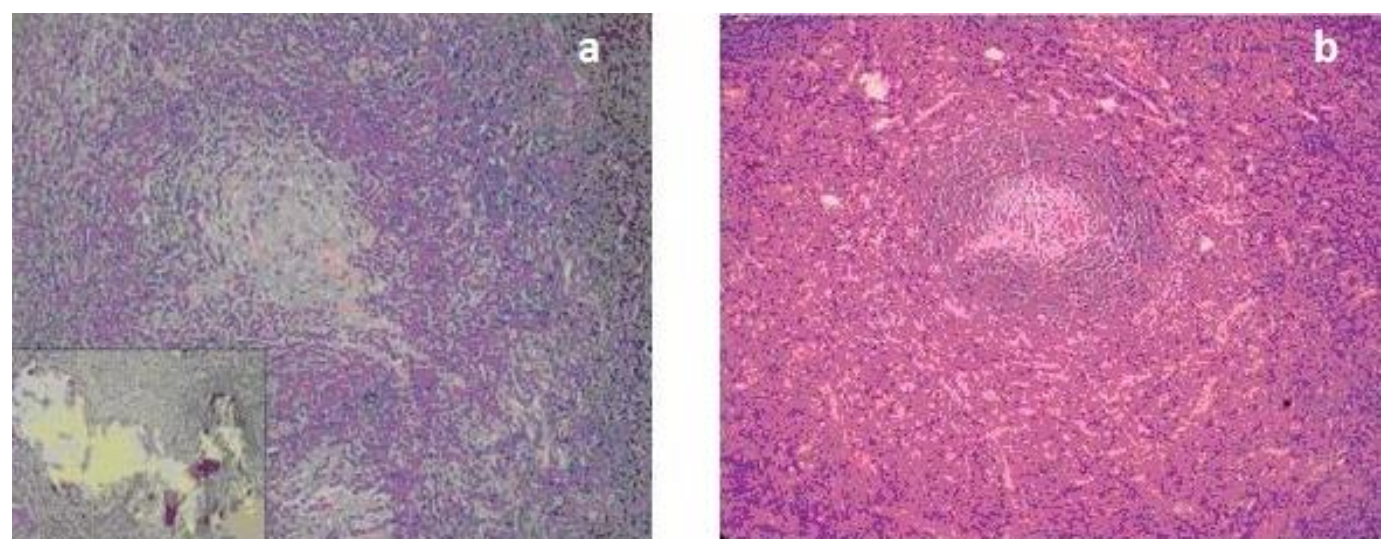

Figure 2: Histopathologic images of the masses. The follicles show atrophic germinal centers with marked vascular proliferation and hyalinization. The follicle is surrounded by a broad mantle zone consisting of a concentric layering of lymphocytes resulting in an onion-skin appearance. Dystrophic calcification is seen in left bottom (H\&E); b) Lymphoid follicles have central hyalinized capillaries with "lollipops" apperance and interfollicular stroma has prominent numerous hyperplastic vessels of the postcapillary venule type (H\&E).

All the patients were operated for abdominal masses. Grossly all the lesions were round, well-circumscribed and encapsulated. The local excision of the masses was performed and the intraoperative frozen section diagnosis of the lesion re- vealed lymphoproliferation. Microscopic examination showed characteristic features of hyaline- vascular type of Castleman Disease including germinal centres which have hyalinized venules. The venules are originating from a hypervascular mantle 
zone. The mantle zone is surrrounded by small lymphocytes in a concentric 'onionskin pattern with focal hyaline deposits (Figure 2). No noteworthy abnormalities were detected by blood tests. Tumor markers (CEA, AFP, CA 19-9, CA 125) were all within normal ranges in all patients. HHV-8 was negative in all pathologic specimens. Patients postoperative courses were without complications. No adjuvant treatment like monoclonal antibodies or radiotherapy was given. Respectively, the follow up periods are sixteen months, fourteen months and twenty-seven months; and no recurrence was found after the follow up periods.

\section{DISCUSSION}

Castleman Disease is an uncommon disorder with benign proliferation of lymphoid tissue. CD is classified as being either localized or disseminated, and is further subdivided into three histological types: the hyaline-vascular type, plasma cell type and mixed type ${ }^{3,9}$. The more frequent type is the hyaline-vascular type (85\%-90\% of cases), which is characterized by abnormal lymphoid follicles, numerous vessels, and wide fibrous septa. The plasma-cell type $(10 \%-15 \%)$ is characterized by large follicles with intervening sheets of plasma cells and few vessels ${ }^{10}$.

$\mathrm{CD}$ occurs frequently in the mediastinum (60\%-70\%). Abdominal forms (10\%-17\%) are localized mainly retroperitoneally. Other locations are less common ${ }^{10,12}$.

In this present, all of our cases with abdominal CD presented with the localized type of hyaline-vascular disease.

The exact cause of $\mathrm{CD}$ remains unknown. A recent report ${ }^{11}$ suggests that the association of CD with HHV-8 and HIV infections. But, the source of immune activation is unclear in HHV-8 and HIV negative patients. IL-6 secretion may be induced from B-lymphocytes by exogenous and endogenous factors. And also, IL-6 secretion may cause $\mathrm{B}$ cell proliferation and vascularization $^{12}$. The identification of the association of HIV and HHV-8 infections with $C D$ has resulted in expansion of understanding of the multicentric type ${ }^{11}$. In addition, systemic symptoms may derived from increased production and circulation of IL-6 in patients with multicentric $\mathrm{CD}^{12}$.

Clinically, localized CD typically has mild biological behaviour, whereas the disseminated form is usually malignant, has a poor prognosis and has severe systemic manifestations ${ }^{9}$. In contrast, the multicentric type of $\mathrm{CD}$ is accompanied by a general lymphadenopathy, systemic symptoms, laboratory abnormalities, organomegaly and progressive clinical course with potential for malignancy and was not recognized until $1978^{13}$.

Three phenotypes of $\mathrm{CD}$ were identified in HIV- patients by Talat et $\mathrm{al}^{15}$ : (a) class I, unicentric hyaline vascular disease; (b) class II, unicentric plasma cell or mixed pathology disease or multicentric hyaline vascular disease; and (c) class III, multicentric plasma cell disease. Class IV CD is diagnosed only in HIV+ patients who have specially multicentric type of plasma cell disease. The 3 year survival rate without the disease were found different among the groups: at $92.5 \%$ for class I patients, $78.8 \%$ for class II patients, and $45.7 \%$ for patients with multicentric plasma cell disease. 3-year disease free survival rate was reported at $27.8 \%$ in Class IV HIV+ patients with multicentric plasma cell disease.

In the first and third cases being reported, apart from abdominal pain, there were no other complaints. In the second case, she did not have any complaints. On physical examination, a palpable mass was realized in the epigastrium of the first patient. In the second and the third cases physical examination was normal. On all of them, acute phase reactants, blood counts, and serological testing for HIV and HHV-8 were also unremarkable; hence a disease of uncertain etiology.

The main issue in retroperitoneal CD lies in the establishment of clinical diagnosis. Imaging methods (ultrasonography, CT and MRI) have been shown to be helpful in the diagnosis; however, localized CD may be clinically and radiographically indistinguishable from other lymphoid and nonlymphoproliferative disorders. $\mathrm{CD}$ is not usually included in the list of possible diagnosis; one of the reasons may be its low 
incidence. CT scan often shows a solid mass with well-defined margins. Dense enhancement immediately after the application of contrast medium is seen. Percutaneous fine-needle aspiration biopsy is often not diagnostic in CD. The histological diagnosis of the disease is based on cell architecture, and therefore requires the study of the entire surgical specimen ${ }^{9-13}$. In our cases, we investigated radiologically. In all cases, well-demarcated retroperitoneal masses were detected. Because of the masses' localization nearby vessels, percutaneous fine-needle aspiration biopsy wasn't applied and we decided to resect all lesions by surgically.

Although the optimal treatment of abdominal CD is yet unknown, surgical excision is generally the option for treatment of both the hyaline-vascular and plasma cell types of localized disease ${ }^{9}$. Retrospective studies revealed that complete resection of the mass provided the best therapeutic option for cure in patients with unicentric hyaline vascular $\mathrm{CD}^{14}$.

There are only a few former reports describing locoregional lymph node seeding in $\mathrm{CD}^{15}$. The rarity of this observation relates to the fact that less than $10 \%$ of all patients operated for $\mathrm{CD}$ had systematic lymphadenectomy. Recently, some authors has demonstrated surgical cure by oncological resection. Schulte et al. ${ }^{16}$ reported that if possible oncological resection must be performed for disseminated CD. When complete resection is impossible, palliative resection or radiotherapy may be used to control possible systemic manifestations ${ }^{4}$, 9. A systemic therapy including chemotherapy, steroid and antiviral therapy should be given to the patients with symptomatic multicentric $\mathrm{CD}$. The use of steroids to supress immun response represents the most important part of therapy and usually results in decrease of symptoms ${ }^{8,9}$. The lesions usually grow slowly, and for patients with extensive comorbidities or questionable health status, conservative management should be considered ${ }^{8}$. In our cases, we performed complete surgical resection and any complication was encountered. On follow up period, no adjuvant treatment like monoclonal antibodies or radiotherapy was given.
In conclusion; $\mathrm{CD}$ should be kept in mind for patients presenting with a retroperitonally localized solid mass. An understanding of the clinical features of this disease, especially in localized form, would help prevent unnecessarily risky or extensive operations for the removal of these benign masses.

\section{REFERENCES}

1. Castleman B, Iverson I, Menendez VP. Localized mediastinal lymphnode hyperplasia resembling thymoma. Cancer 1956; 9:822-30.

2. Flendrig JA. Benign giant lymphoma: clinicopathologic correlation study. Clark RL, Cumle RW, eds. The year book of cancer. Chicago: Year Book Medical Publishers 1970.

3. Keller AR, Hochholzer L, Castleman B. Hyaline-vascular and plasma-cell types of giant lymph node hyperplasia of the mediastinum and other locations. Cancer 1972; 29:670-83.

4. Chen CH, Liu HC, Tung KY, Lee JJ, Liu CL, Liu TP. Surgical outcome of superficial and deep Castleman disease. ANZ J Surg 2007; 77: 339-43.

5. Martino G, Cariati S, Tintisona $\mathrm{O}$, Veneroso S, De Villa F, Vergine M, Monti M. Atypical lymphoproliferative disorders: Castleman's disease. Case report and review of the literature. Tumori 2004; 90: 352-5.

6. Frizzera G, Peterson BA, Bayrd ED, Goldman A. A systemic lymphoproliferative disorder with morphologic features of Castleman's disease: clinical findings and clinicopathologic correlations in 15 patients. J Clin Oncol 1985; 3: 1202-16.

7. Ridolfini MP, Rotondi F, Gourgiotis S, Alfieri S, Di Miceli D, Larocca LM, Doglietto GB. Retroperitoneal Castleman's disease. A report of two cases and analysis of the literature. Chir Ital 2007; 59: 53-61.

8. Colakoglu T, Ezer A, Kocer E, Yıldırım S, Belli S. Castleman's 
disease mimicking right adrenal neoplasm: A case report .Turk $\mathbf{J}$ Gastroenterol 2011; 22: 551-4.

9. Han SL, Chen XX, Zheng XF, Yan JY,Shen X, Zhu GB. The clinicopathological behaviour and surgical treatment of abdominal Castleman's disease. Singapore Med J 2010; 51: 813.

10. Čečka F, Ferko A, Jon B, Subrt Z, Kasparova P, Repak R .Pancreatic Castleman disease treated with laparoscopic distal pancreatectomy. Hepatobiliary Pancreat Dis Int 2013; 12: 332-4.

11. Yamasaki S, Iino T, Nakamura $M$, Henzan H, Ohshima K, Kikuchi M, Otsuka T, Harada M. Detection of human herpesvirus-8 in peripheral blood mononuclear cells from adult Japanese patients with multicentric Castleman's disease. $\mathrm{Br} \mathrm{J}$ Haematol 2003; 120: 471-7.

12. Casper C. The aetiology and management of Castleman disease at 50 years: translating pathophysiology to patient care. Br J Haematol 2005; 129: 3-17.

13. Gaba AR, Stein RS, Sweet DL, Variakojis D. Multicentric giant lymph node hyperplasia. Am J Clin Pathol 1978; 69: 86-90.

14. Bowne WB, Lewis JJ, Filippa DA, Niesvizky R, Brooks AD, Burt ME, Brennan MF. The management of unicentric and multicentric Castleman's disease: a report of 16 cases and a review of the literature. Cancer 1999; 85: 706-17.

15. Talat N, Schulte K. Castleman's Disease: Systematic Analysis of 416 Patients from the Literature. The Oncologist2011; 16:1316-24.

16. Schulte K, Sinha P, Talat N, DiazCano S. Retroperitoneal unicentric Castleman's disease with multiplelymph node involvement. BMJ Case Reports 2011. 